\section{Effect of chemical treatment on the physiological and sanitary quality of stored coffee seeds}

\author{
Amanda Carvalho Penido ${ }^{1 *}$ (D) , Vitor Oliveira Rodrigues ${ }^{1}$ (D) Marcos Vinícios \\ de Carvalho ${ }^{1}$, Levi Suzigan Krepischi $^{1}$ iD, Cristiane Carvalho Pereira ${ }^{1}$ (D), \\ João Almir Oliveira ${ }^{1}$
}

ABSTRACT: Maintaining the health of coffee seeds is especially important during storage, as soil fungi and storage fungi can considerably reduce seed quality. Thus, chemical treatments for protection of seeds in storage becomes important in agricultural production. It is necessary to evaluate the effects of these treatments on seedling development and the protection they provide against storage fungi, aiming at seed longevity and preventing rapid deterioration. The aim of this study was to evaluate the effect of chemical treatment on the physiological and sanitary quality of stored coffee seeds. Seeds of five Coffea arabica cultivars were pre-dried, treated with Vitavax ${ }^{\circledR}$ Thiram, and placed in cold storage at $10{ }^{\circ} \mathrm{C}$ for nine months. Seed physiological quality was evaluated every three months by the germination test and by determination of root emergence percentage, seedlings with expanded cotyledonary leaves, and seedling dry matter. Seed health quality was assessed by the health test. The chemical treatment with Vitavax-Thiram does not affect the physiological quality of stored Coffea arabica seeds. Seed treatment before storage is effective in reducing the inoculum potential of Fusarium spp. and Phoma spp. in coffee seeds.

Index terms: conservation, Vitavax-Thiram, Fusarium spp., Phoma spp., Coffea arabica.

\section{Influência do tratamento químico na qualidade fisiológica e sanitária de sementes de café armazenadas}

RESUMO: A qualidade sanitária é um atributo importante em sementes de café, principalmente durante o armazenamento, pois a presença de fungos de solo e de armazenamento são importantes causadores de perda da qualidade. Assim, o tratamento químico visando a proteção das sementes durante o armazenamento, torna-se importante na produção agrícola, sendo necessário a avaliação dos efeitos dos produtos no desenvolvimento das plântulas e na proteção contra os fungos de armazenamento, visando a longevidade das sementes e evitar a rápida deterioração. Portanto, o objetivo foi avaliar o efeito do tratamento químico na qualidade fisiológica e sanitária de sementes de café armazenadas. Foram utilizadas sementes da espécie Coffea arabica, estas foram présecadas, tratadas com Vitavax ${ }^{\oplus}$ Thiram e armazenadas em câmara fria a $10^{\circ} \mathrm{C}$ durante nove meses. A qualidade fisiológica foi avaliada a cada três meses pelo teste de germinação, protrusão radicular, plântulas com folhas cotiledonares expandidas e massa seca de plântulas. A avaliação da qualidade sanitária foi realizada pelo teste de sanidade. $O$ tratamento químico com Vitavax ${ }^{\circledR}$ Thiram não afeta a qualidade fisiológica das sementes de Coffea arabica armazenadas. $\mathrm{O}$ tratamento de sementes antes do armazenamento é eficiente na redução do potencial de inóculo dos patógenos Fusarium spp. e Phoma spp. em sementes de café.

Termos para indexação: conservação, Vitavax-Thiram, Fusarium spp., Phoma spp., Coffea arabica.
Journal of Seed Science, v.43, e202143009, 2021

http://dx.doi.org/10.1590/ 2317-1545v43237239

\footnotetext{
*Corresponding author E-mail: apenidoufla@gmail.com
}

Received: $27 / 4 / 2020$. Accepted: 13/1/2021.

${ }^{1}$ Departamento de Agricultura, Universidade Federal de Lavras (UFLA), Caixa Postal 3037, 37200900 - Lavras, MG, Brasil. 


\section{INTRODUCTION}

Coffee is an important product in the world market and is produced and consumed in various countries. Brazil holds a prominent position in this market as it is the largest producer and exporter of coffee in the world.

Coffee is generally grown commercially through planting of seedlings, and high-quality seeds are essential for success in obtaining these seedlings (Trujillo et al., 2019). One of the greatest difficulties for coffee seedling producers is that coffee seeds are harvested and need to be sown within a relatively short period, since they rapidly lose viability. However, seeds are harvested beginning in June, when temperatures are low, which hinders seedling development.

Thus, it is necessary to store these seeds in order to produce the seedlings at times more favorable to their development. Yet coffee seeds are considered intermediate in relation to tolerance to desiccation (Hong and Ellis, 1992), that is, they partially tolerate water loss during drying and storage at low temperatures. Since coffee seeds are intermediate seeds (Roberts, 1973), maintaining their quality during the storage period is more difficult.

Among the many factors that affect seed quality, seed health is of great importance, especially during storage. Fungi that proliferate during storage are important causes of loss of seed quality over the storage period. For that reason, chemical seed treatment is necessary as a form of seed protection during storage that also offers protection in the initial stages of the crop during seedling formation. It thus becomes possible to maintain seed physiological quality and effective control and prevention of attacks from pathogens and pests (Silva et al., 2020). Chemical treatment aiming at seed protection during storage becomes increasingly important in agricultural production and, consequently, evaluation of the effect of the chemical treatment on seed quality has been the objective of studies in various species, such as brachiaria grass (Seraguzi et al., 2018), soybean (Abati et al., 2020), wheat (Munareto et al., 2018), and maize (Mariucci et al., 2018).

The product Vitavax ${ }^{\circledR}$-Thiram 200 SC is a broad-spectrum fungicide, with a formulation that contains a systemic fungicide (carboxin - $200 \mathrm{~g} / \mathrm{L}$ ) and a contact fungicide (thiram - $200 \mathrm{~g} / \mathrm{L}$ ). It is recommended for most crops of economic interest, such as rice, dry bean, soybean, maize, and cotton, with the function of protecting seeds against fungal attack during the initial stages of seedling development and also during storage (AGROFIT, 2020). However, for the coffee crop, there is no recommendation of this product or other registration in the Brazilian Ministry of Agriculture (Ministério da Agricultura, Pecuária e Abastecimento - MAPA) for seed treatment. In addition, few studies with coffee have been performed using chemical products registered in MAPA for other crops, such as in the study of Ferreira et al. (2010) using a product of active ingredients Carbendazim $(150 \mathrm{~g} / \mathrm{L})$ and Thiram $(350 \mathrm{~g} / \mathrm{L})$ to assess the transmissibility of the fungus Colletotrichum gloeosporioides and the effect of treatment of coffee seeds in the presence of this disease.

As a consequence, nursery workers have used products not registered for coffee growing as a form of protection against and elimination of pathogens. Studies are still necessary on the use of chemical products that prove to be effective for use in coffee seeds. Through such studies it will be possible to clarify the effect of the product on seedling development as well as in protection against storage fungi with the aim of increasing seed longevity and avoiding rapid deterioration. Therefore, the aim of this study was to evaluate the effect of chemical treatment on the physiological and sanitary quality of stored coffee seeds.

\section{MATERIAL AND METHODS}

The study was carried out in the Central Seed Laboratory of the Department of Agriculture of the Universidade Federal de Lavras (UFLA). We used newly-harvested high moisture seeds from the 2017 crop season of the species Coffea arabica L., cultivars Catuaí Vermelho IAC 144 (39.16 \%), Mundo Novo IAC 376/4 (38.24 \%), Catiguá MG2 (29.80 \%), MGS Aranãs (40.39\%), and Topázio MG 1190 (40.82 \%), provided by the Empresa de Pesquisa Agropecuária de Minas Gerais (EPAMIG), which were already being commercialized.

The product Vitavax-Thiram 200 SC was used as chemical treatment on parchment coffee seeds at the dose of $3 \mathrm{~mL}$ 
of product $/ \mathrm{kg}$ of seed, with the addition of $10 \mathrm{~mL}$ of water. Plastic bags of 2-kg capacity were used to apply the product on the seeds. First water was added to the product, forming a mixture of $13 \mathrm{~mL} / \mathrm{kg}$ of seed, which was placed in the plastic bags together with the seed. All of this was worked until obtaining a homogeneous mixture of product and seed. After the treatment, the seeds were placed in the shade at a temperature of approximately $25^{\circ} \mathrm{C}$ for a period of 60 minutes to dry the product on the seed surface. Another portion of the seeds did not receive any chemical treatment, but only the same amount of water was added before the seeds were stored, thus composing treated seeds and seeds without chemical treatment for each cultivar.

After the treatment, the parchment coffee seeds were separated into portions in reference to each storage period, placed in conventional raffia bags, and covered by another waterproof plastic bag. The bags were placed in cold storage at $10{ }^{\circ} \mathrm{C}$. Samples were taken every three months over a period of nine months for determination of quality by the following tests and determinations:

Determination of moisture content: carried out by the laboratory oven method at $105^{\circ} \mathrm{C} / 24 \mathrm{~h}$ (Brasil, 2009b) with two 20-g samples. The weight results obtained in wet basis were expressed in percentage.

Germination test: carried out using four replications of 50 seeds, removing the parchment from the seeds before setting up the test. The seeds were distributed on germination paper and moistened with water in the amount of 2.5 times the weight of the dry paper. The seeds were kept in a seed germinator regulated to the temperature of $30^{\circ} \mathrm{C}$, and the percentage of normal seedlings was evaluated after 30 days, following the Rules for Seed Testing (Brasil, 2009b).

Root emergence: performed at 15 days after the beginning of the germination test, when the seedlings with radicle emergence were counted, and the results were expressed in percentage.

Seedlings with expanded cotyledonary leaves: conducted at 45 days after the beginning of the germination test when the seedlings that had fully expanded cotyledonary leaves were counted, and the results were expressed in percentage.

Seedling dry matter: conducted according to the germination test, with four replications of 50 seeds. At 30 days after sowing, the final reading of the germination test was made and the seedlings considered normal (Brasil, 2009b) were kept in the germinator for 15 more days, for a total of 45 days. After that, the hypocotyl-radicle axes of the seedlings were separated into paper bags and placed in an air-circulation laboratory oven at $60{ }^{\circ} \mathrm{C}$ for five days. After that period, the dry matter of the roots and shoots of the seedlings was determined, and the results were expressed in grams per seedling.

Seed health test: performed with eight replications of 25 seeds, using three sheets of filter paper placed in 15-cm diameter Petri dishes with a fine layer of 1.0\% agar-agar. The filter paper was moistened with a 2,4D solution. The seeds that received chemical treatment were incubated for 10 days, and those that did not receive any treatment remained for 7 days (Brasil, 2009a). At the end of the incubation period, the seeds were individually analyzed with the aid of a stereoscopic magnifying glass and optical microscope for identification and quantification of fungi. The results obtained were expressed in percentage of infected seeds.

Experimental design and statistical analyses: a completely randomized experimental design was used in a $2 \times 4 \times 5$ factorial arrangement, consisting of two chemical treatments (treated and untreated), four storage periods $(0,3,6$, and 9 months), and the five cultivars used. Analysis of variance was performed on the data, and means comparison at a $5 \%$ significance level was performed by the Scott-Knott test, with assistance of the SISVAR ${ }^{\circledast}$ software (Ferreira, 2011). For the quantitative data referring to the storage period, regression was performed; however, the coefficient of determination $\left(R^{2}\right)$ for most of the equations was less than $70 \%$. Thus, analysis was performed through the means in reference to the original data.

\section{RESULTS AND DISCUSSION}

Based on the results of analysis of variance, there was double interaction between the cultivar and storage period factors for the root emergence variable. The cultivars studied differentiated from each other after six months of storage (Table 1, Figure 1), where comparison between the cultivars shows greater reduction in root emergence of the cultivars 
Topázio and Catiguá MG2, and in the latter, there was an even greater decline at 9 months of storage.

There was also a significant interaction between the chemical treatment and storage period factors for the same variable in question. The chemical treatment did not affect the root emergence percentage of the seeds over the storage period (Table 2), although a lower value was observed at 6 months for those seeds that received the chemical treatment. However, at 0,3 , and 9 months of storage, this effect among the treatments was not observed, and we can therefore conclude that for these periods, the treatment did not have a phytotoxic effect on the seedlings coming from the treated seeds.

The treated seeds and those that did not receive the chemical treatment had similar results in root emergence percentage. Therefore, there was no negative effect from the use of the chemical product applied on the coffee seeds, except for those at 6 months of storage (Figure 2).

Table 1. Seed root emergence (\%) of the $C$. arabica cultivars over the storage period.

\begin{tabular}{ccccc}
\hline \multirow{2}{*}{ Cultivar } & \multicolumn{4}{c}{ Storage period } \\
\cline { 2 - 5 } & 0 months & 3 months & 6 months & 9 months \\
\hline Catuaí Vermelho IAC 144 & $94.00 \mathrm{~A}$ & $96.00 \mathrm{~A}$ & $88.00 \mathrm{~A}$ & $88.00 \mathrm{~A}$ \\
Mundo Novo IAC 376/4 & $93.00 \mathrm{~A}$ & $94.00 \mathrm{~A}$ & $88.00 \mathrm{~A}$ & $89.00 \mathrm{~A}$ \\
Catiguá MG2 & $91.00 \mathrm{~A}$ & $92.00 \mathrm{~A}$ & $84.00 \mathrm{~B}$ & $77.00 \mathrm{~B}$ \\
MGS Aranãs & $92.00 \mathrm{~A}$ & $94.00 \mathrm{~A}$ & $92.00 \mathrm{~A}$ & $92.00 \mathrm{~A}$ \\
Topázio MG 1190 & $93.00 \mathrm{~A}$ & $93.00 \mathrm{~A}$ & $85.00 \mathrm{~B}$ & $89.00 \mathrm{~A}$ \\
\hline
\end{tabular}

The mean values followed by the same letter in the column do not differ from each other by the Scott-Knott test at $5 \%$ probability.

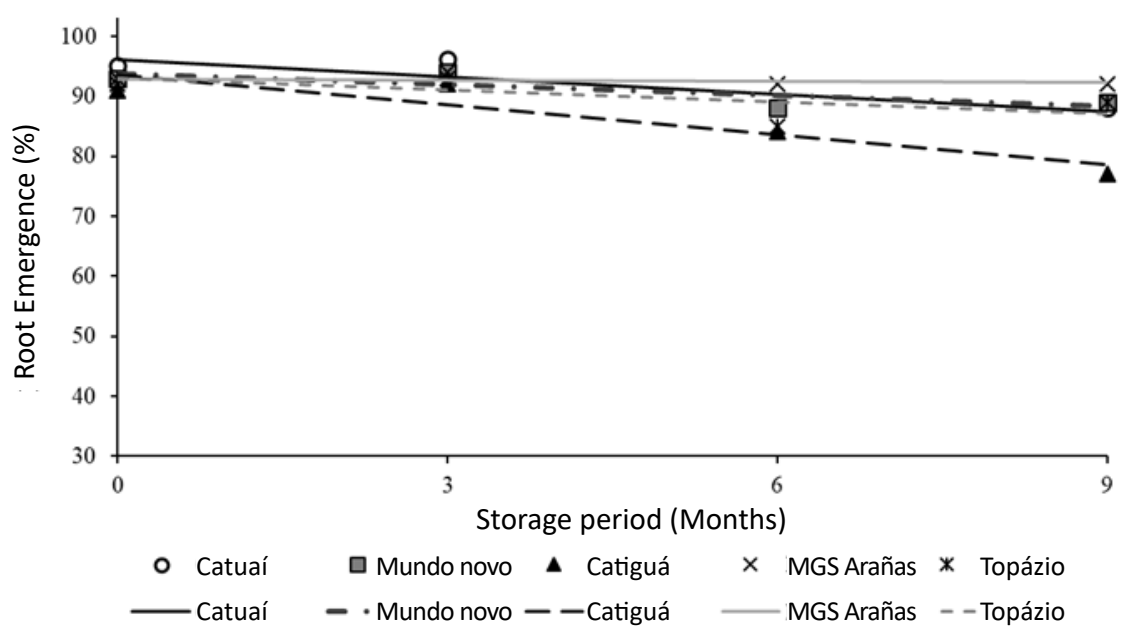

Figure 1. Root emergence (\%) from seeds of $C$. arabica cultivars according to storage period.

Table 2. Root emergence (\%) of Coffea arabica seeds under chemical treatment over the storage period.

\begin{tabular}{ccccc}
\hline \multirow{2}{*}{ Chemical treatment } & \multicolumn{4}{c}{ Storage period } \\
\cline { 2 - 5 } & 0 months & 3 months & 6 months & 9 months \\
\hline Yes & $94.00 \mathrm{~A}$ & $93.00 \mathrm{~A}$ & $85.00 \mathrm{~B}$ & $88.00 \mathrm{~A}$ \\
No & $92.00 \mathrm{~A}$ & $94.00 \mathrm{~A}$ & $89.00 \mathrm{~A}$ & $86.00 \mathrm{~A}$ \\
\hline
\end{tabular}

The mean values followed by the same letter in the column do not differ from each other by the Scott-Knott test at $5 \%$ probability. 


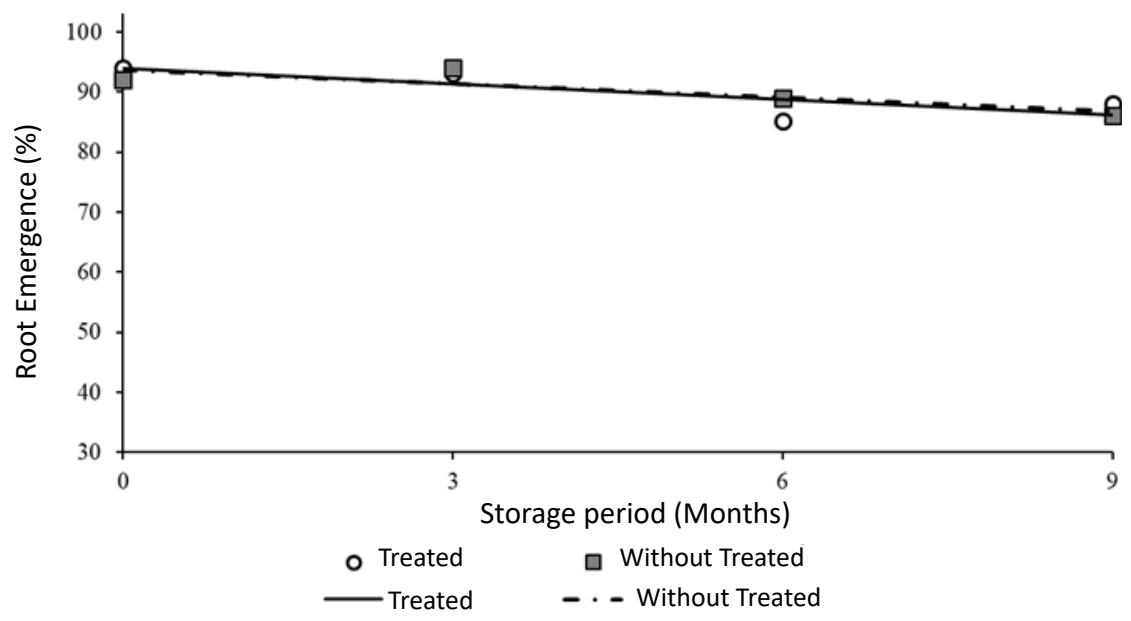

Figure 2. Root emergence (\%) from Coffea arabica seeds according to chemical treatment and control after storage periods.

Table 3. Seed germination (\%) of different Coffea arabica cultivars during the storage period.

\begin{tabular}{ccccc}
\hline \multirow{2}{*}{ Cultivar } & \multicolumn{4}{c}{ Storage period } \\
\cline { 2 - 5 } & 0 months & 3 months & 6 months & 9 months \\
\hline Catuaí Vermelho IAC 144 & $83.00 \mathrm{~A}$ & $78.00 \mathrm{~B}$ & $79.00 \mathrm{~B}$ & $83.00 \mathrm{~B}$ \\
Mundo Novo IAC 376/4 & $81.00 \mathrm{~A}$ & $81.00 \mathrm{~B}$ & $76.00 \mathrm{C}$ & $80.00 \mathrm{~B}$ \\
Catiguá MG2 & $76.00 \mathrm{~B}$ & $83.00 \mathrm{~B}$ & $74.00 \mathrm{C}$ & $65.00 \mathrm{C}$ \\
MGS Aranãs & $83.00 \mathrm{~A}$ & $86.00 \mathrm{~A}$ & $85.00 \mathrm{~A}$ & $88.00 \mathrm{~A}$ \\
Topázio MG 1190 & $85.00 \mathrm{~A}$ & $88.00 \mathrm{~A}$ & $80.00 \mathrm{~B}$ & $85.00 \mathrm{~A}$ \\
\hline
\end{tabular}

The mean values followed by the same letter in the column do not differ from each other by the Scott-Knott test at $5 \%$ probability.

In the results of the germination test (Table 3), significant interaction of the factors was also observed, just as occurred for root emergence percentage. Of the newly-harvested seeds, only the cultivar Catiguá MG2 had germination results lower than those of the other cultivars.

This lower result of the seed germination percentage of the cultivar Catiguá MG2 can be explained by the lower moisture content of the seeds, $29 \%$, while that of the other cultivars was around $40 \%$. Some authors assert that, in general, better conservation of coffee seeds can be attributed to their high moisture content, at values such as $32 \%$ in permeable packaging (Araujo et al., 2008) and 35\% in sealed plastic bags under cold chamber controlled (Braccini et al., 1998).

After 3 months of storage, the cultivars differed from each other in relation to germination percentage and, in subsequent periods, these differences were of greater intensity. These results show that even under the same storage conditions, there is a different response of the different Coffea arabica cultivars regarding seed deterioration over the storage period.

In spite of the different responses of the cultivars over the storage period, they maintained the minimum germination potential after 9 months of storage required by MAPA for sale of coffee seeds, except for the cultivar Catiguá MG2 (Figure 3), in which the germination percentage declined to $65 \%$, therefore below the standard required for commercialization (70\%), according to government ordinance - Portaria $n^{\circ} 388$ IMA (2000).

The effect of chemical treatment on stored seeds can be observed in Table 4, with better performance of treated seeds in relation to untreated seeds soon after harvest. Over the storage period, differences are not found between treated and untreated seeds, except at six months, in which, just as occurred for root emergence percentage, the treated seeds had a lower germination percentage. Nevertheless, at 0,3 , and 9 months, this effect is not observed, thus 
confirming that the product did not have a phytotoxic effect.

A similar response of treated and untreated seeds is likewise found over the storage period (Figure 4), showing that the chemical treatment does not hinder seed germination over storage; however, there is no gain in physiological quality of the seeds from the treatment through possible elimination of pathogens.

Most of the cultivars showed little difference regarding development of cotyledonary leaves in the coffee seedlings coming from seeds under the chemical treatment (Table 5), confirming that the use of the chemical product did not hurt seed quality over the storage period in regard to seedling vigor.

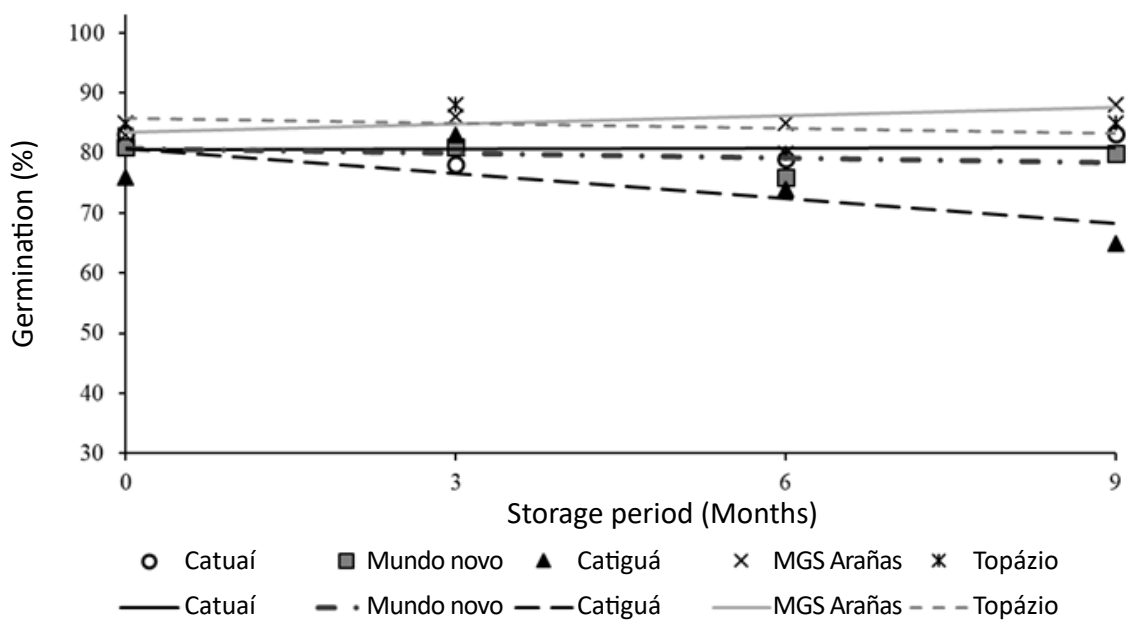

Figure 3. Germination (\%) of seeds of different Coffea arabica cultivars according to the storage period.

Table 4. Germination (\%) of Coffea arabica seeds under chemical treatment during the storage period.

\begin{tabular}{ccccc}
\hline \multirow{2}{*}{ Chemical treatment } & \multicolumn{4}{c}{ Storage period } \\
\cline { 2 - 5 } & 0 months & 3 months & 6 months & 9 months \\
\hline Yes & $83.00 \mathrm{~A}$ & $83.00 \mathrm{~A}$ & $76.00 \mathrm{~B}$ & $81.00 \mathrm{~A}$ \\
No & $80.00 \mathrm{~B}$ & $83.00 \mathrm{~A}$ & $84.00 \mathrm{~A}$ & $80.00 \mathrm{~A}$ \\
\hline
\end{tabular}

The mean values followed by the same letter in the column do not differ from each other by the Scott-Knott test at $5 \%$ probability.

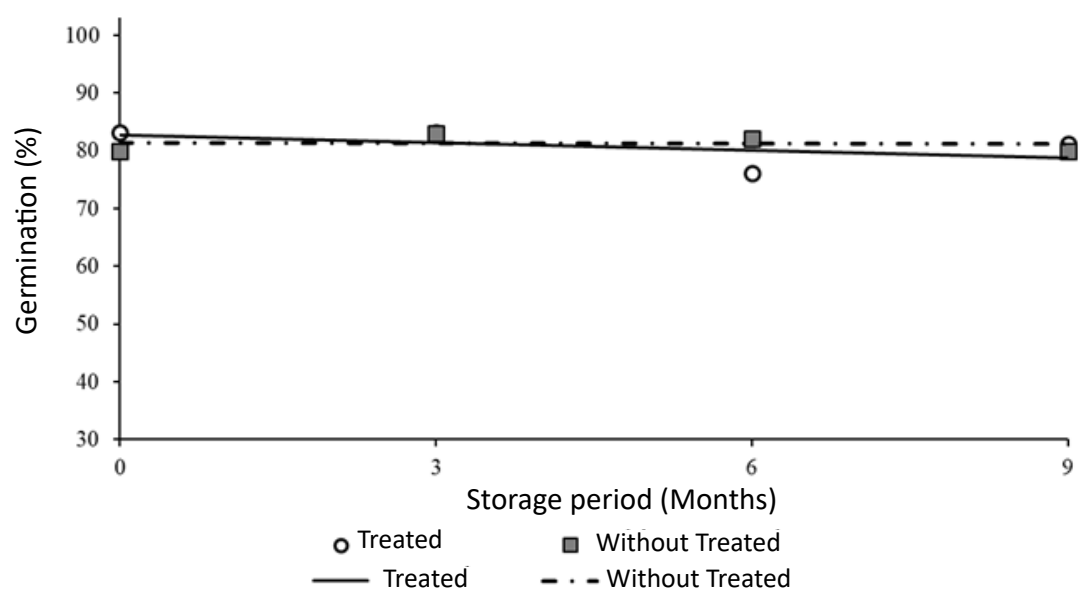

Figure 4. Germination (\%) of Coffea arabica seeds according to chemical treatment and control after storage periods. 
Table 5. Percentage of expanded cotyledonary leaves at 45 days after sowing seeds of Coffea arabica cultivars.

\begin{tabular}{cccc}
\hline \multirow{2}{*}{ Storage (months) } & Cultivar & Chemical treatment \\
\cline { 2 - 3 } & Catuaí Vermelho IAC 144 & $77.00 \mathrm{Aa}$ & with \\
\hline & Mundo Novo IAC 376/4 & $78.00 \mathrm{Aa}$ & $76.00 \mathrm{Aa}$ \\
& Catiguá MG2 & $74.00 \mathrm{Ba}$ & $67.00 \mathrm{Bb}$ \\
& MGS Aranãs & $68.00 \mathrm{Bb}$ & $78.00 \mathrm{Aa}$ \\
& Topázio MG 1190 & $80.00 \mathrm{Aa}$ & $82.00 \mathrm{Aa}$ \\
\hline \multirow{2}{*}{3} & Catuaí Vermelho IAC 144 & $62.00 \mathrm{Bb}$ & $69.00 \mathrm{Ba}$ \\
& Mundo Novo IAC 376/4 & $59.00 \mathrm{Bb}$ & $70.00 \mathrm{Ba}$ \\
& Catiguá MG2 & $59.00 \mathrm{Ba}$ & $55.00 \mathrm{Ca}$ \\
& MGS Aranãs & $73.00 \mathrm{Aa}$ & $68.00 \mathrm{Ba}$ \\
& Topázio MG 1190 & $75.00 \mathrm{Aa}$ & $79.00 \mathrm{Aa}$ \\
\hline & Catuaí Vermelho IAC 144 & $82.00 \mathrm{Aa}$ & $65.00 \mathrm{Bb}$ \\
& Mundo Novo IAC 376/4 & $77.00 \mathrm{Aa}$ & $66.00 \mathrm{Bb}$ \\
& Catiguá MG2 & $68.00 \mathrm{Ba}$ & $61.00 \mathrm{Ba}$ \\
& MGS Aranãs & $81.00 \mathrm{Aa}$ & $80.00 \mathrm{Aa}$ \\
& Topázio MG 1190 & $80.00 \mathrm{Aa}$ & $70.00 \mathrm{Bb}$ \\
\hline
\end{tabular}

The mean values followed by the same uppercase letter in the column for each storage time and lowercase letter in the row do not differ from each other by the Scott-Knott test at $5 \%$ probability.

Differences in the percentage of seedlings with cotyledonary leaves arising from treated and untreated seeds in each storage period were not observed. However, the graphs in Figure 5 show that the chemically treated seeds had a similar response in relation to seedling vigor during storage. In the cultivars without chemical treatment, greater oscillation is observed for the same trait evaluated, with a greater decline in the number of cotyledonary leaves after 6 months. Furthermore, it is noteworthy that the Catiguá cultivar had a greater reduction in percentage of cotyledonary leaves when coming from untreated seeds; and when the seeds were treated, vigor was maintained (Figure 5).

Treating seeds with fungicides is an important measure in protecting seeds during storage, and it may ensure an adequate population of plants and their good development after sowing (Zorato and Henning, 2001). Araujo et al. (2019) also observed improvements in the physiological quality of castor bean seeds chemically treated with Derosal and Vitavax-Thiram compared to those without treatment at 12 months of storage.

Ribeiro et al. (2018) studied alternative treatments for conserving arabica coffee seeds and found that seeds treated with the chemical product mancozeb had root length superior to that of the seedlings obtained from seeds without any treatment over a 15-month storage period.

Evaluation of root dry matter of the seedlings shows that at most of the storage times, the response of the cultivars in relation to chemical treatment is similar, there being no difference among the plants coming from treated seeds and from those that did not receive chemical treatment (Table 6). Analysis of the effect of chemical treatment shows differences among the cultivars even before storage (newly-harvested seeds), and greater differences are found over the storage period. 

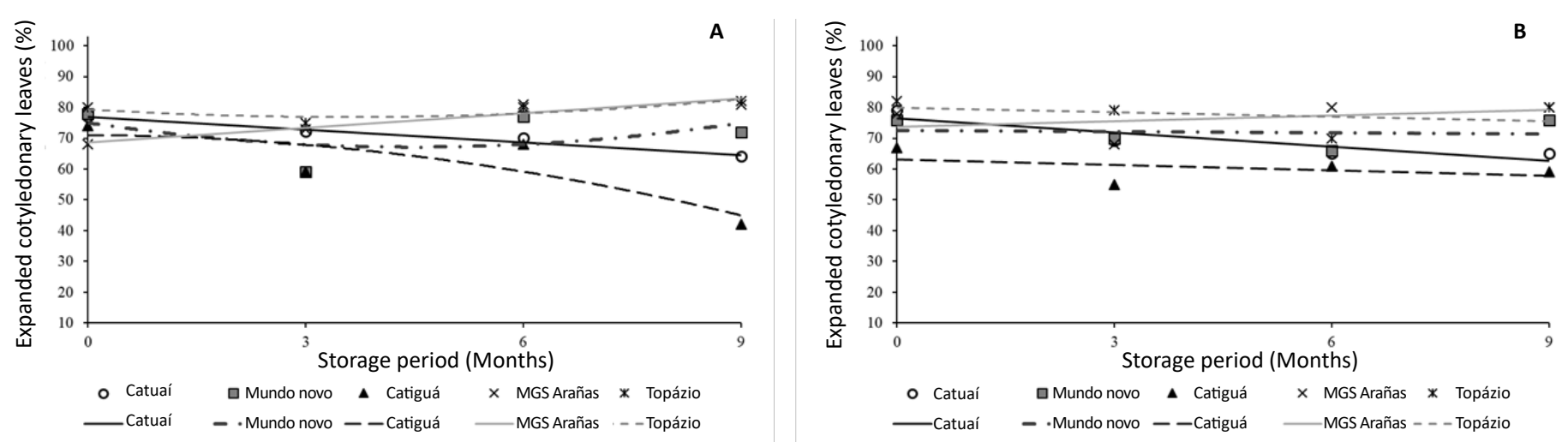

Figure 5. Expanded cotyledonary leaves (\%) at 45 days after sowing seeds of Coffea arabica cultivars under chemical treatment $(B)$ and without treatment $(A)$ during storage.

Table 6. Root (R) and shoot (S) dry matter ( $\mathrm{g}$ ) of seedlings at 45 days coming from seeds of Coffea arabica cultivars.

\begin{tabular}{|c|c|c|c|c|c|}
\hline \multirow{3}{*}{$\begin{array}{l}\text { Storage time } \\
\text { (months) }\end{array}$} & \multirow{3}{*}{ Cultivar } & \multirow{2}{*}{\multicolumn{2}{|c|}{$\frac{\mathrm{R}}{\text { Chemical treatment }}$}} & \multirow{2}{*}{\multicolumn{2}{|c|}{$\frac{\mathrm{S}}{\text { Chemical treatment }}$}} \\
\hline & & & & & \\
\hline & & without & with & without & with \\
\hline \multirow{5}{*}{0} & Catuaí Vermelho IAC 144 & $0.32 \mathrm{Ba}$ & $0.35 \mathrm{Ba}$ & $1.60 \mathrm{Ba}$ & $1.73 \mathrm{Aa}$ \\
\hline & Mundo Novo IAC 376/4 & $0.35 \mathrm{Aa}$ & $0.32 \mathrm{Ba}$ & $1.77 \mathrm{Aa}$ & $1.78 \mathrm{Aa}$ \\
\hline & Catiguá MG2 & $0.29 \mathrm{Ba}$ & $0.29 \mathrm{Ba}$ & $1.36 \mathrm{Ca}$ & $1.26 \mathrm{Ba}$ \\
\hline & MGS Aranãs & $0.39 \mathrm{Aa}$ & $0.41 \mathrm{Aa}$ & $1.42 \mathrm{Cb}$ & $1.85 \mathrm{Aa}$ \\
\hline & Topázio MG 1190 & $0.28 \mathrm{Bb}$ & $0.34 \mathrm{Ba}$ & $1.54 \mathrm{Ba}$ & $1.68 \mathrm{Aa}$ \\
\hline \multirow{5}{*}{3} & Catuaí Vermelho IAC 144 & $0.22 \mathrm{Ba}$ & $0.23 \mathrm{Ba}$ & $1.27 \mathrm{Ba}$ & $1.39 \mathrm{Ba}$ \\
\hline & Mundo Novo IAC 376/4 & $0.19 \mathrm{Ba}$ & $0.23 \mathrm{Ba}$ & $1.39 \mathrm{Bb}$ & $1.62 \mathrm{Aa}$ \\
\hline & Catiguá MG2 & $0.23 \mathrm{Ba}$ & $0.16 \mathrm{Cb}$ & $1.29 \mathrm{Ba}$ & $1.10 \mathrm{Cb}$ \\
\hline & MGS Aranãs & $0.29 \mathrm{Aa}$ & $0.30 \mathrm{Aa}$ & $1.64 \mathrm{Aa}$ & 1.52 Ba \\
\hline & Topázio MG 1190 & $0.22 \mathrm{Bb}$ & $0.30 \mathrm{Aa}$ & $1.43 \mathrm{Bb}$ & $1.71 \mathrm{Aa}$ \\
\hline \multirow{5}{*}{6} & Catuaí Vermelho IAC 144 & $0.32 \mathrm{Aa}$ & $0.25 \mathrm{Bb}$ & $1.79 \mathrm{Aa}$ & $1.37 \mathrm{Cb}$ \\
\hline & Mundo Novo IAC 376/4 & $0.34 \mathrm{Aa}$ & $0.24 \mathrm{Bb}$ & $1.79 \mathrm{Aa}$ & $1.59 \mathrm{Bb}$ \\
\hline & Catiguá MG2 & $0.27 \mathrm{Ba}$ & $0.24 \mathrm{Ba}$ & $1.43 \mathrm{Ba}$ & $1.26 \mathrm{Cb}$ \\
\hline & MGS Aranãs & $0.33 \mathrm{Aa}$ & $0.34 \mathrm{Aa}$ & $1.89 \mathrm{Aa}$ & $1.90 \mathrm{Aa}$ \\
\hline & Topázio MG 1190 & $0.28 \mathrm{Ba}$ & $0.24 \mathrm{Ba}$ & $1.73 \mathrm{Aa}$ & $1.38 \mathrm{Cb}$ \\
\hline \multirow{5}{*}{9} & Catuaí Vermelho IAC 144 & $0.14 \mathrm{Ca}$ & $0.11 \mathrm{Ca}$ & $1.06 \mathrm{Da}$ & $1.00 \mathrm{Ba}$ \\
\hline & Mundo Novo IAC 376/4 & $0.24 \mathrm{Ba}$ & $0.26 \mathrm{Aa}$ & $1.36 \mathrm{Cb}$ & $1.52 \mathrm{Aa}$ \\
\hline & Catiguá MG2 & $0.11 \mathrm{Cb}$ & $0.16 \mathrm{Ba}$ & $0.67 \mathrm{~Eb}$ & $0.97 \mathrm{Ba}$ \\
\hline & MGS Aranãs & $0.34 \mathrm{Aa}$ & $0.27 \mathrm{Ab}$ & $1.94 \mathrm{Aa}$ & $1.50 \mathrm{Ab}$ \\
\hline & Topázio MG 1190 & $0.23 \mathrm{Ba}$ & $0.20 \mathrm{Ba}$ & $1.63 \mathrm{Ba}$ & $1.40 \mathrm{Ab}$ \\
\hline
\end{tabular}

The mean values followed by the same uppercase letter in the column for each storage time and lowercase letter in the row for each variable do not differ from each other by the Scott-Knott test at $5 \%$ probability. 
The results of shoot dry matter of the seedlings (Table 6) show that for the newly-harvested seeds, there were no differences in the use of chemical treatment, except for the cultivar MGS Aranãs, in which the results for shoot dry matter are higher in seedlings from untreated seeds than in seedlings from treated seeds. In the other storage periods, the cultivars have a different response. At 6 months of storage, most of the cultivars had better results of shoot dry matter when the seeds did not receive chemical treatment.

Ishikawa et al. (2012) also observed better results in the development of wheat seedlings obtained from seeds without chemical treatment with carboxin + thiram and difenoconazole. The authors report that these fungicides negatively affect wheat plant growth.

The graph representations in Figure 6 show that in analysis of root dry matter of coffee seedlings, the cultivars had the same type of response when under chemical treatment (Figure 6B) and without application of the product (Figure 6A). Vigor declined as of six months of storage, especially for the cultivars Catiguá and Catuaí Vermelho, whether the chemical product was used or not.

In analysis of the mean values of the original data, greater oscillation in the results of shoot dry matter (Figures 6C and 6D) was found over the storage period. Seedlings coming from seeds without treatment have a greater decline in vigor after 6 months of storage for the cultivars Catuaí Vermelho, Catiguá, and Mundo Novo. Comparison of these same cultivars under chemical treatment exhibits a more homogeneous response and smaller decline in shoot dry matter over the storage period.
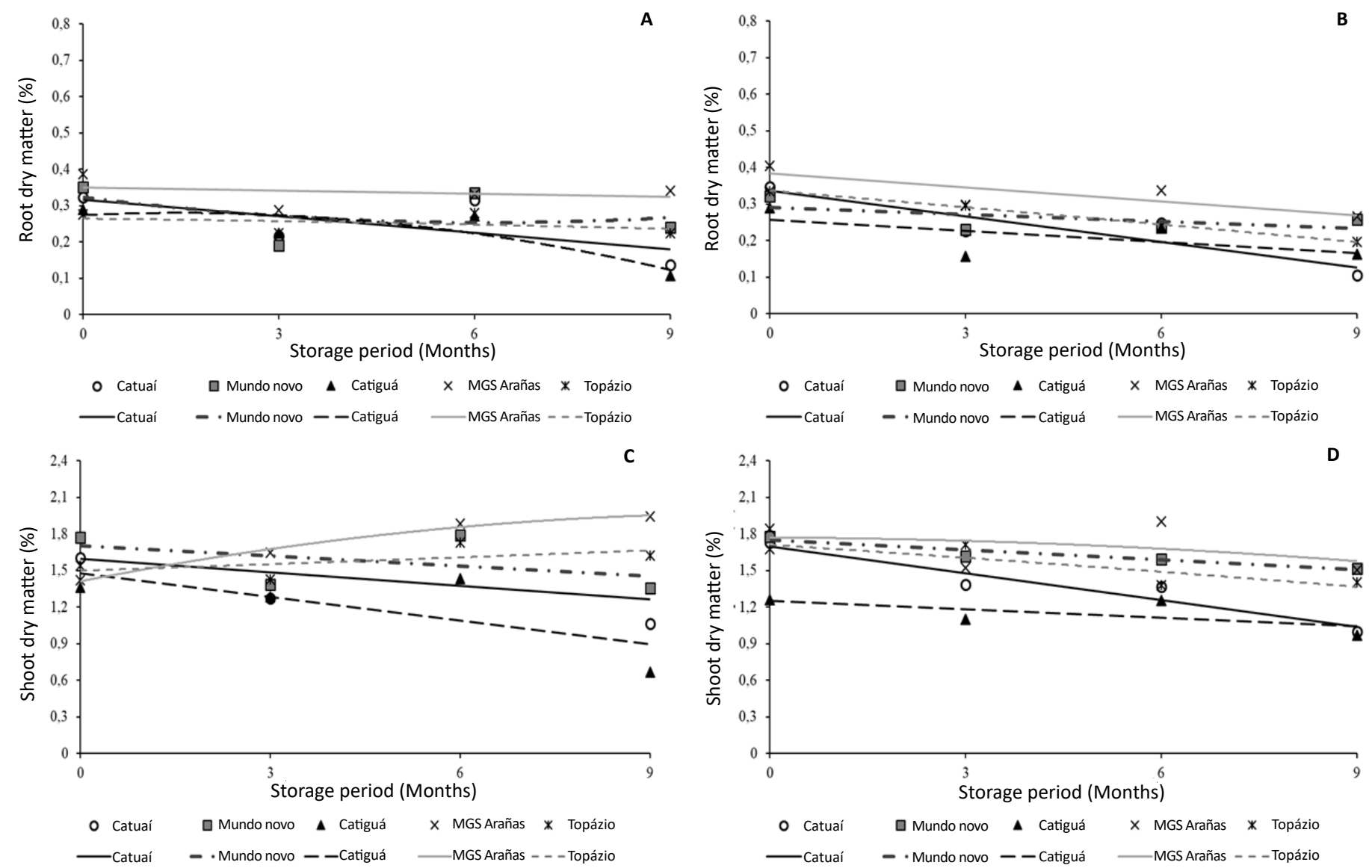

Figure 6. Root dry matter (g) of seedlings at 45 days after sowing seeds of coffee cultivars under chemical treatment (B) and without treatment $(\mathrm{A})$ during storage; Shoot dry matter $(\mathrm{g})$ of coffee cultivars under chemical treatment (D) and without treatment (C) during storage. 
The plant health test for assessment of the presence of pathogens in coffee seeds over the storage period revealed four pathogens: Aspergillus spp., Fusarium spp., Penicillium spp., and Phoma spp., occurring in all the storage periods in the seeds, though some have low levels of infestation, as shown in Table 7.

The seeds of all the cultivars used had a low incidence of the pathogens Aspergillus spp. and Penicillium spp., even during storage, and, therefore, the use of the chemical treatment did not bring about positive effects on the occurrence of these pathogens in the seeds (Table 7$)$; the low temperature conditions $\left(10^{\circ} \mathrm{C}\right.$ ) were not promising for development of these fungi. The occurrence of the pathogens Fusarium spp. and Phoma spp. declines with the use of the chemical treatment, showing that the use of the product was effective in control of these pathogens for most of the cultivars during the storage period.

The incidence of the fungal pathogen Fusarium spp. increased over the storage period in most of the cultivars, regardless of the use of chemical treatment. Nevertheless, in the treated seeds, the infestation rate was lower from the beginning of storage on, showing that seed treatment can be an ally in reducing the inoculum potential in coffee seeds (Figure 7.2).

Braccini et al. (1999) relate the occurrence of microorganisms with the type of packaging used during storage of coffee seeds. The authors found greater occurrence of the fungus Fusarium semitectum in seeds kept in kraft paper bags and cotton bags. In addition, they report that in coffee seeds stored in polyethylene packaging, there is reduction

Table 7. Occurrence of pathogens (\%) in seeds of Coffea arabica cultivars under chemical treatment and without treatment over the storage period.

\begin{tabular}{|c|c|c|c|c|c|c|c|c|c|}
\hline \multirow{4}{*}{$\begin{array}{l}\text { Storage } \\
\text { (months) }\end{array}$} & \multirow{4}{*}{ Cultivar } & \multicolumn{8}{|c|}{ Pathogen } \\
\hline & & \multirow{2}{*}{\multicolumn{2}{|c|}{$\begin{array}{c}\text { Aspergillus spp. } \\
\text { Chemical treatment }\end{array}$}} & \multirow{2}{*}{\multicolumn{2}{|c|}{$\begin{array}{c}\text { Fusarium spp. } \\
\text { Chemical treatment }\end{array}$}} & \multirow{2}{*}{\multicolumn{2}{|c|}{$\begin{array}{c}\text { Penicillium spp. } \\
\text { Chemical treatment }\end{array}$}} & \multirow{2}{*}{\multicolumn{2}{|c|}{$\begin{array}{c}\text { Phoma spp. } \\
\text { Chemical treatment }\end{array}$}} \\
\hline & & & & & & & & & \\
\hline & & without & with & without & with & without & with & without & with \\
\hline \multirow{5}{*}{0} & Catuaí Vermelho IAC 144 & $0.00 \mathrm{Aa}$ & $1.00 \mathrm{Aa}$ & $57.00 \mathrm{Bb}$ & $29.00 \mathrm{Aa}$ & $3.00 \mathrm{Aa}$ & $3.00 \mathrm{Aa}$ & $26.00 \mathrm{Aa}$ & $21.00 \mathrm{Aa}$ \\
\hline & Mundo Novo IAC 376/4 & $3.00 \mathrm{Aa}$ & $2.00 \mathrm{Aa}$ & $42.00 \mathrm{Aa}$ & $35.00 \mathrm{Aa}$ & $1.00 \mathrm{Aa}$ & $2.00 \mathrm{Aa}$ & $71.00 \mathrm{Cb}$ & $53.00 \mathrm{Ba}$ \\
\hline & Catiguá MG2 & $8.00 \mathrm{Ba}$ & $8.00 \mathrm{Ba}$ & $53.00 \mathrm{Bb}$ & $37.00 \mathrm{Aa}$ & $3.00 \mathrm{Aa}$ & $6.00 \mathrm{Aa}$ & $55.00 \mathrm{Ba}$ & $54.00 \mathrm{Ba}$ \\
\hline & MGS Aranãs & $8.00 \mathrm{Ba}$ & $8.00 \mathrm{Ba}$ & $47.00 \mathrm{Ab}$ & $33.00 \mathrm{Aa}$ & $4.00 \mathrm{Aa}$ & $4.00 \mathrm{Aa}$ & $84.00 \mathrm{Db}$ & $62.00 \mathrm{Ca}$ \\
\hline & Topázio MG 1190 & $1.00 \mathrm{Aa}$ & $0.00 \mathrm{Aa}$ & $78.00 \mathrm{Cb}$ & $48.00 \mathrm{Ba}$ & $8.00 \mathrm{Ba}$ & $6.00 \mathrm{Aa}$ & $26.00 \mathrm{Aa}$ & $25.00 \mathrm{Aa}$ \\
\hline \multirow{5}{*}{3} & Catuaí Vermelho IAC 144 & $2.00 \mathrm{Aa}$ & $4.00 \mathrm{Ba}$ & $53.00 \mathrm{Aa}$ & $56.00 \mathrm{Ba}$ & $3.00 \mathrm{Aa}$ & $5.00 \mathrm{Aa}$ & $57.00 \mathrm{Cb}$ & $19.00 \mathrm{Aa}$ \\
\hline & Mundo Novo IAC 376/4 & $5.00 \mathrm{Aa}$ & $8.00 \mathrm{Ca}$ & $63.00 \mathrm{Ba}$ & $60.00 \mathrm{Ba}$ & $3.00 \mathrm{Aa}$ & $6.00 \mathrm{Aa}$ & $65.00 \mathrm{Bb}$ & $33.00 \mathrm{Ba}$ \\
\hline & Catiguá MG2 & $4.00 \mathrm{Aa}$ & $6.00 \mathrm{Ba}$ & $71.00 \mathrm{Bb}$ & $61.00 \mathrm{Ba}$ & $3.00 \mathrm{Aa}$ & $4.00 \mathrm{Aa}$ & $58.00 \mathrm{Cb}$ & $35.00 \mathrm{Ba}$ \\
\hline & MGS Aranãs & $5.00 \mathrm{Aa}$ & $8.00 \mathrm{Ca}$ & $55.00 \mathrm{Ab}$ & $27.00 \mathrm{Aa}$ & $7.00 \mathrm{Aa}$ & $7.00 \mathrm{Aa}$ & $81.00 \mathrm{Ab}$ & $50.00 \mathrm{Ca}$ \\
\hline & Topázio MG 1190 & $2.00 \mathrm{Aa}$ & $0.00 \mathrm{Aa}$ & $63.00 \mathrm{Ba}$ & $62.00 \mathrm{Ba}$ & $2.00 \mathrm{Aa}$ & $4.00 \mathrm{Aa}$ & $58.00 \mathrm{Cb}$ & $22.00 \mathrm{Aa}$ \\
\hline \multirow{5}{*}{6} & Catuaí Vermelho IAC 144 & $1.00 \mathrm{Aa}$ & $2.00 \mathrm{Aa}$ & $80.00 \mathrm{Bb}$ & $57.00 \mathrm{Ba}$ & $5.00 \mathrm{Ba}$ & $6.00 \mathrm{Ba}$ & $35.00 \mathrm{Cb}$ & $14.00 \mathrm{Aa}$ \\
\hline & Mundo Novo IAC 376/4 & $2.00 \mathrm{Aa}$ & $2.00 \mathrm{Aa}$ & $82.00 \mathrm{Bb}$ & $59.00 \mathrm{Ba}$ & $8.00 \mathrm{Ba}$ & $8.00 \mathrm{Ba}$ & $43.00 \mathrm{Db}$ & $22.00 \mathrm{Ba}$ \\
\hline & Catiguá MG2 & $15.00 \mathrm{Cb}$ & $3.00 \mathrm{Aa}$ & $74.00 \mathrm{Ab}$ & $59.00 \mathrm{Ba}$ & $18.00 \mathrm{Ca}$ & $16.00 \mathrm{Ca}$ & $31.00 \mathrm{Bb}$ & $13.00 \mathrm{Aa}$ \\
\hline & MGS Aranãs & $6.00 \mathrm{Ba}$ & $4.00 \mathrm{Aa}$ & $65.00 \mathrm{Ab}$ & $23.00 \mathrm{Aa}$ & $7.00 \mathrm{Ba}$ & $8.00 \mathrm{Ba}$ & $73.00 \mathrm{~Eb}$ & $30.00 \mathrm{Ca}$ \\
\hline & Topázio MG 1190 & $0.00 \mathrm{Aa}$ & $0.00 \mathrm{Aa}$ & $91.00 \mathrm{Cb}$ & $49.00 \mathrm{Ba}$ & $1.00 \mathrm{Aa}$ & $2.00 \mathrm{Aa}$ & $23.00 \mathrm{Aa}$ & $21.00 \mathrm{Ba}$ \\
\hline \multirow{5}{*}{9} & Catuaí Vermelho IAC 144 & $1.00 \mathrm{Aa}$ & $2.00 \mathrm{Aa}$ & $74.00 \mathrm{Ab}$ & $54.00 \mathrm{Aa}$ & $11.00 \mathrm{Aa}$ & $12.00 \mathrm{Aa}$ & $12.00 \mathrm{Ab}$ & $2.00 \mathrm{Aa}$ \\
\hline & Mundo Novo IAC 376/4 & 4.00 Ba & $1.00 \mathrm{Aa}$ & $77.00 \mathrm{Ab}$ & $58.00 \mathrm{Aa}$ & $9.00 \mathrm{Aa}$ & $10.00 \mathrm{Aa}$ & $27.00 \mathrm{Bb}$ & $19.00 \mathrm{Ca}$ \\
\hline & Catiguá MG2 & $5.00 \mathrm{Ba}$ & $4.00 \mathrm{Aa}$ & $73.00 \mathrm{Aa}$ & $66.00 \mathrm{Ba}$ & $27.00 \mathrm{Ca}$ & $25.00 \mathrm{Ca}$ & $18.00 \mathrm{Ab}$ & $9.00 \mathrm{Ba}$ \\
\hline & MGS Aranãs & $3.00 \mathrm{Ba}$ & $3.00 \mathrm{Aa}$ & $70.00 \mathrm{Ab}$ & $52.00 \mathrm{Aa}$ & $24.00 \mathrm{Ca}$ & $29.00 \mathrm{Db}$ & $45.00 \mathrm{Cb}$ & $17.00 \mathrm{Ca}$ \\
\hline & Topázio MG 1190 & $1.00 \mathrm{Aa}$ & $0.00 \mathrm{Aa}$ & $89.00 \mathrm{Bb}$ & $76.00 \mathrm{Ca}$ & $20.00 \mathrm{Ba}$ & $17.00 \mathrm{Ba}$ & $15.00 \mathrm{Aa}$ & $9.00 \mathrm{Ba}$ \\
\hline
\end{tabular}

The mean values followed by the same uppercase letter in the column for each storage time and lowercase letter in the row for each fungus do not differ from each other by the Scott-Knott test at $5 \%$ probability. 

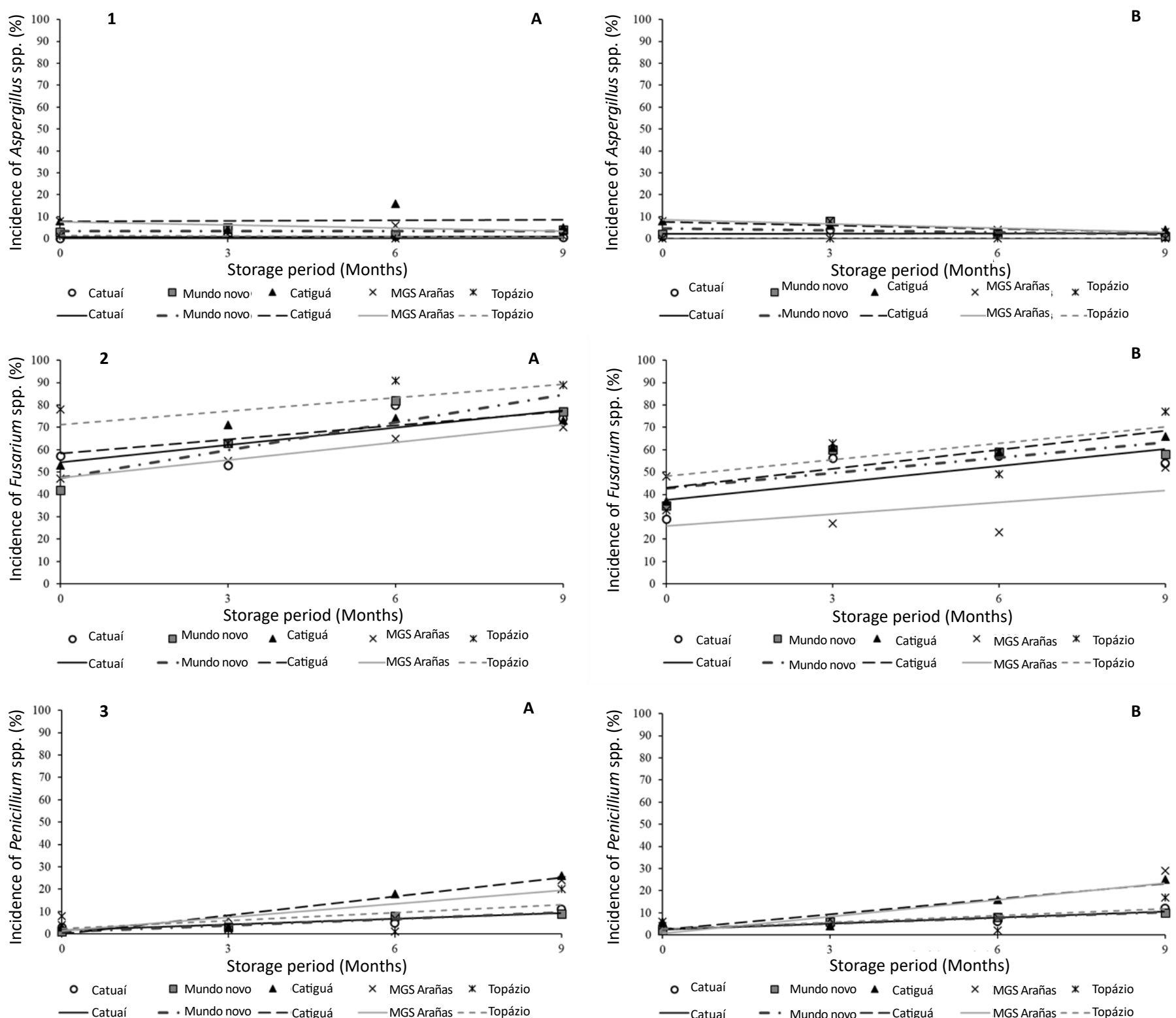

—Catuaí _ Mundo novo - - Catiguá — MGS Arañas - - -Topázio
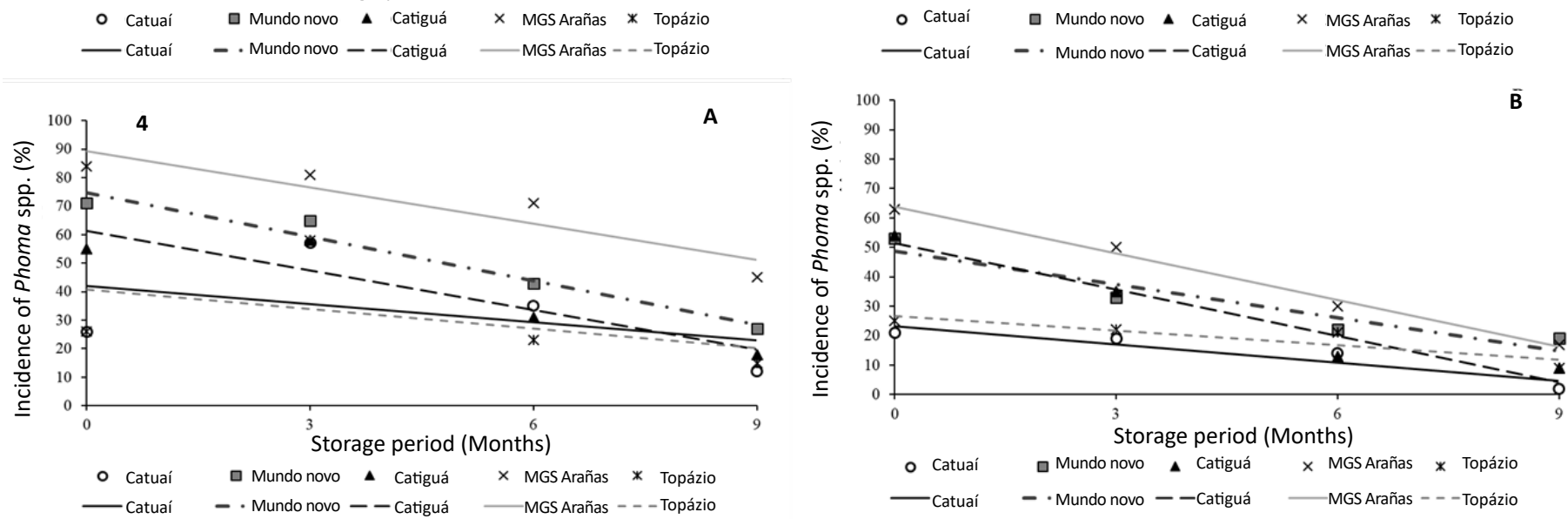

Figure 7. Incidence (\%) of the pathogens Aspergillus spp. (1), Fusarium spp. (2), Penicillium spp. (3), and Phoma spp. (4) in seeds of five coffee cultivars without chemical treatment $(A)$ and treated (B) over the storage period. 
in the occurrence of this fungus soon at the beginning of storage with moisture content of $35 \%$ and $25 \%$, thus diverging from what was observed in this study.

Analysis of the incidence of the pathogen Penicillium spp. shows that the seeds of the cultivars used had a similar response, with low infestation of this fungus. Nevertheless, its occurrence increases over the storage period, regardless of the use of seed treatment (Figure 7.3). In addition, chemical treatment was not able to reduce or eliminate this pathogen in the seeds (Table 7).

The seeds of all the cultivars used had a high incidence level of the fungal pathogen Phoma spp., which declined over the storage period. This pathogen is considered a field fungus; therefore, a decline in its incidence during storage is normal, due to conditions unfavorable to its development. However, an even greater reduction in incidence of the pathogen occurs in treated seeds after 3 months of storage, showing the effectiveness of the product in control of the pathogen (Figure 7.4). Ferreira et al. (2010) also observed a reduction in the incidence of Phoma spp. in coffee seeds after the chemical treatment with the active ingredients benzimidazole + dimethyldithiocarbamate.

Corroborating the results found here, Dias and Barros (1993) found low incidence of the storage fungi Penicillium spp. and Aspergillus spp. in Coffea arabica seeds during the seed assessment period.

\section{CONCLUSIONS}

The use of chemical treatment with the product Vitavax ${ }^{\circledR}$-Thiram does not affect the physiological quality of stored Coffea arabica seeds.

Seed treatment before storage is effective in reducing the inoculum potential of the pathogens Fusarium spp. and Phoma spp. in coffee seeds.

\section{REFERENCES}

ABATI, J.; BRZEZINSKI, C.R.; BERTUZZI, E.C.; HENNING, F.A.; ZUCARELI, C. Physiological response of soybean seeds to spray volumes of industrial chemical treatment and storage in different environments. Journal of Seed Science, v.42, e202042002, 2020. https:// doi.org/10.1590/2317-1545v42221062

AGROFIT. Ministério da Agricultura, Pecuária e Abastecimento. Sistema de Agrotóxicos Fitossanitários. http://agrofit.agricultura. gov.br/agrofit_cons/principal_agrofit_cons

ARAUJO, R.F.; ARAUJO, E.F.; CECON, P.R.; SOFIATTI, V. Conservação de sementes de café (Coffea arabica L.) despolpado e não despolpado. Revista Brasileira de Sementes, v.30, n.3, p.71-78, 2008. https://doi.org/10.1590/S0101-31222008000300010

ARAUJO, R.F.; ZONTA, J.B.; ARAUJO, E.F.; LEAL, C.A.M. Tratamentos alternativos para conservação de sementes de mamona (Ricinus communis L.). Summa Phytopathologica, v.45, n.1, p.89-96, 2019. https://doi.org/10.1590/0100-5405/187494

BRACCINI, A.L.; BRACCINI, M.C.L.; CAPIM, C.A.; OLIVEIRA, V.R.; ANDRADE, C.A.B.; Conservação de sementes de café robusta (Coffea canephora Pierre ex Froehner) cultivar Conillon em função do grau de umidade e do tipo de embalagem. Revista Brasileira de Sementes, v.20, n.2, p.160-169, 1998. https://www.abrates.org.br/files/artigos/58984c47c948d2.69193475_artigo27.pdf

BRACCINI, A.L.; SCAPIM, C.A.; BRACCINI, M.C.L.; ANDRADE, C.A.B.; VIDIGAL-FILHO, P.S. Incidência de microorganismos em sementes de café robusta durante o armazenamento. Bragantia, v.58, n.2, p.305-315, 1999. https://doi.org/10.1590/S000687051999000200010

BRASIL. Ministério da Agricultura, Pecuária e Desenvolvimento. Manual de análise sanitária de sementes. Ministério da Agricultura, Pecuária e Abastecimento. Secretaria de Defesa Agropecuária. Brasília: MAPA/ACS, 2009a. 202p. http://www.agricultura.gov.br/ assuntos/insumos-agropecuarios/insumos-agricolas/sementes-e-mudas/publicacoes-sementes-e-mudas/manual-de-analisesanitaria-de-sementes/view

BRASIL. Ministério da Agricultura, Pecuária e Desenvolvimento. Regras para análise de sementes. Ministério da Agricultura, Pecuária e Abastecimento. Secretaria de Defesa Agropecuária. Brasília: MAPA/ACS, 2009b. 399p. http:// www.agricultura.gov.br/ arq_editor/file/2946_regras_analise_sementes.pdf 
DIAS, M.C.L.L.; BARROS, A.S.R. Conservação de sementes de café (Coffea arabica L.) em diferentes embalagens. Revista Brasileira de Sementes, v.15, n.2, p.197-202, 1993. http://dx.doi.org/10.17801/0101-3122/rbs.v15n2p197-202

FERREIRA, D.F. Sisvar: a computer statistical analysis system. Ciência e Agrotecnologia, v.35, n.6, p.1039-1042, 2011. http://www. scielo.br/scielo.php?script=sci_arttext\&pid=S1413-70542011000600001

FERREIRA, J.B.; ABREU, M.S.; MACHADO, J.C.; PEREIRA, I.S.; FERNANDES, K.D. Transmissibilidade e efeito do tratamento de sementes de cafeeiros com mancha manteigosa (C. gloeosporioides). Ciência e Agrotecnologia, v.34, n.1, p.101-108, 2010. https:// doi.org/10.1590/S1413-70542010000100013

HONG, T.D.; ELLIS, R.H. Development of desiccation tolerance in Norway maple (Acer platanoides L.) seeds during maturation drying. Seed Science Research, v.2, n.3, p.169-172, 1992. https://doi.org/10.1017/S0960258500001306

IMA. INSTITUTO MINEIRO DE AGROPECUÁRIA. Normas e padrões para a produção de sementes básicas e fiscalizadas de café. Portaria no 388, de 22 de maio de 2000. Belo Horizonte, 2000. http://www.ima.mg.gov.br/institucional/portarias\#ano-2000. Accessed on: 29 Oct, 2020.

ISHIKAWA, M.S.; FONSECA, I.C.B.; IGARASHI, S. Tratamento químico de sementes sobre o desenvolvimento de mancha marrom em plantas de trigo. Ciência Rural, v.42, n.8, p. 1341-1346, 2012. https://doi.org/10.1590/S0103-84782012000800002

MARIUCCI, G.E.G.; SUZUKAWA, A.K.; BRACCINI, A.L.; SCAPIM, C.A.; LIMA, L.H.S.; ANGELOTTI, P.; PONCE, R.M.; MARTELI, D.C.V. Physiological potential of maize seeds submitted to different treatments and storage periods. Journal of Seed Science, v.40, n.1, p.60-66, 2018. https://doi.org/10.1590/2317-1545v40n1184456

MUNARETO, J.D.; MARTIN, T.N.; MÜLLER, T.M.; NUNES, U.R.; ROSA, G.B.; GRANDO, L.F.T. Compatibility of Azospirillum brasilense with fungicide and insecticide and its effects on the physiological quality of wheat seeds. Semina: Ciências Agrárias, v.39, n.2, p.855-864, 2018. https://doi.org/10.5433/1679-0359.2018v39n2p855

RIBEIRO, M.F.; ARAÚJO, E.F.; PINTO, C.L.O.; ARAÚJO, R.F.; RIBEIRO, M.R.F. Germination of coffee seed treated with medicinal plants. Acta Horticulturae, v.1198, p.59-62, 2018. https://doi.org/10.17660/actahortic.2018.1198.11

ROBERTS, E.H. Predicting the storage life of seeds. Seed Science and Technology, v.1, p.499-514, 1973.

SERAGUZI, E.F.; REGO, C.H.Q.; CARDOSO, F.B.; CÂNDIDO, A.C.S.; ALVES, C.Z. Physiological quality of Brachiaria brizantha seeds treated with fungicide and insecticide. Revista Caatinga, v.31, n.3, p.651-656, 2018. https://doi.org/10.1590/1983-21252018v31n313rc

SILVA, K.M.J.; VON PINHO, R.G.; VON PINHO, E.V.R.; OLIVEIRA, R.M.; SANTOS, H.O.; SILVA, T.S. Chemical treatment and size of corn seed on physiological and sanitary quality during storage. Journal of Seed Science, v.42, e202042010, 2020. https://doi. org/10.1590/2317-1545v42219569

TRUJILLO, H.A.; GOMES-JUNIOR, F.G.; CICERO, S.M. Digital images of seedling for evaluating coffee seed vigor. Journal of Seed Science, v.41, n.1, p.60-68, 2019. https://doi.org/10.1590/2317-1545v41n1204651

ZORATO, M.; HENNING, A. Influência de tratamento fungicidas antecipados, aplicados em diferentes épocas de armazenamento, sobre a qualidade de sementes de soja. Revista Brasileira de Sementes, v.23, n.2, p.236-244, 2001. https://doi.org/10.17801/01013122/rbs.v23n2p236-244 use, distribution, and reproduction in any medium, provided the original work is properly cited. 